\title{
Kepemimpinan Sekolah Dasar di Masa Covid-19
}

\author{
Ana Fitrotun Nisa*1, Nurwiarsih ${ }^{2}$ \\ ${ }^{1}$ Universitas Sarjanawiyata Tamansiswa Yogyakarta \\ ${ }^{2}$ Institut Agama Islam Ibrahimy Genteng Banyuwangi \\ *Email korespondensi: ananisa@ymail.com
}

\begin{abstract}
Abstact
The coronavirus disease (covid-19) pandemic demands all aspects including the world of education to carry out lockdowns or self-quarantine in an effort to minimize the spread of covid19. This forces policy makers in schools to be able to adapt to various alternative activities that are adapted to existing developments. This article aims to describe the leadership of primary schools during the Covid-19 period which was carried out at SD Lazuardi Tursina Banyuwangi. The research method used is descriptive qualitative method. The subjects of this study were the director, principal and teachers at SD Lazuardi Tursina Banyuwangi. The data collection technique is done by interview, observation and documentation. The data analysis technique is done by reducing the data, presenting the data and drawing conclusions. The results showed that the leadership carried out in the management of SD Lazuardi Tursina during the covid-19 period included: 1) simplifying the curriculum; 2) coordination and intense discussion between directors, principals and teachers regarding the adjustment of learning techniques, strategies, models and methods; 3) more flexible budget management; 4) continuous evaluation of policies that have been implemented; 5) good communication between schools and parents; and 6) good cooperation with various aspects.
\end{abstract}

Keyword: Leadership, Primary Schoool, Covid-19.

\section{Abstrak}

Pandemi coronavirus disease (covid-19) menuntut semua aspek termasuk dunia pendidikan untuk melakukan lockdown atau karantina mandiri sebagai upaya meminimalisir penyebaran covid-19. Hal tersebut memaksa para pemangku kebijakan di sekolah untuk mampu menyesuaikan diri dengan berbagai alternatif-alternatif kegiatan yang disesuaikan dengan perkembangan yang ada. Artikel ini bertujuan untuk memaparkan kepemimpinan sekolah dasar pada masa covid-19 yang dilakukan di SD Lazuardi Tursina Banyuwangi. Metode penelitian yang digunakan adalah metode deskriptif kualitatif. Subjek penelitian ini adalah direktur, kepala sekolah dan guru di SD Lazuardi Tursina Banyuwangi. Teknik pengumpulan data dilakukan dengan wawancara, observasi dan dokumentasi. Teknik analisis data dilakukan dengan reduksi data, penyajian data dan penarikan kesimpulan. Hasil penelitian menunjukkan bahwa kepemimpinan yang dilakukan dalam pengelolaan di SD Lazuardi Tursina pada masa covid-19 ini antara lain yaitu dengan melakukan: 1) penyederhanaan kurikulum; 2) koordinasi dan diskusi secara intens antara direktur, kepala sekolah dengan guru-guru terkait penyesuaian teknik, strategi, model dan metode pembelajaran yang dilakukan; 3) pengelolaan anggaran yang lebih fleksibel; 4) evaluasi secara berkelanjutan terhadap kebijakan yang telah dilaksanakan; 5) komunikasi yang baik antara sekolah dengan orang tua; dan 6) kerjasama yang baik dengan berbagai aspek.

Kata Kunci: Kepemimpinan, Sekolah Dasar, Covid-19 


\section{A. Pendahuluan}

Coronavirus disease (Covid-19) merupakan virus yang pertama kali mewabah di Wuhan, Hubei, Cina (Huang et.al, 2020: 497). Virus ini dengan mudah menular dan dengan cepatnya menyebar ke seluruh penjuru dunia. Adanya covid-19 tidak hanya memporakporandakan Wuhan China, namun di berbagai belahan dunia termasuk Indonesia. Tidak hanya berpengaruh pada aspek kesehatan dan ekonomi, namun juga berpengaruh pada keberlangsungan aspek pendidikan.

Dalam upaya meminimalisir penyebaran covid, lembaga pendidikan ditutup sementara yang berdampak pada gangguan proses pembelajaran (Aji, 2020). Pada masa pandemi ini waktu, lokasi, dan jarak menjadi permasalahan besar (Kusuma \& Hamidah, 2020). Di sisi lain, pendidikan juga dituntut untuk harus tetap berjalan sesuai dengan peranannya agar tujuan yang hendak dicapai dapat tetap terwujud dengan baik.

Solusi yang diberikan dalam pelaksanaan pendidikan di masa covid-19 yaitu dengan melakukan pembelajaran melalui online atau biasa disebut dengan pembelajaran dalam jaringan (daring). Model pembelajaran daring yang digunakan guru sekolah dasar antara lain memanfaatkan aplikasi whatsapps, google, zoom, dan youtube (Anugrahana, 2020). Praktik pembelajaran daring pada pendidikan dasar dilakukan melalui bimbingan orang tua (Dewi, 2020) sehingga tujuan pembelajaran dapat dipantau dengan baik.

Pada kenyataannya, pembelajaran daring bukanlah sesuatu yang mudah khususnya bagi orang tua wali yang selama ini telah mempercayakan seutuhnya proses pembelajaran anak kepada sekolah. Saat ini orang tua harus turut memastikan proses belajar dari rumah ini berjalan dengan baik. Orang tua juga harus mampu menguasai teknologi yang digunakan dalam pembelajaran daring. Selain itu, orang tua juga berperan sebagai motivator anak dengan membantu kesulitan-kesulitan yang dihadapi anak selama belajar (Wardhani, 2020). Orang tua perlu menyediakan waktu yang cukup untuk mendampingi dan menfasilitasi kegiatan belajar siswa.

Pelaksanaan pembelajaran daring penting untuk dievaluasi sesuai dengan kondisi setempat mengingat sebaran fasilitas dan kemampuan orang tua 
memberikan fasilitas pembelajaran daring berbeda kepada peserta didik (Herliandry, dkk, 2020). Tidak semua orang tua mampu menguasai teknologi yang digunakan dalam pembelajaran daring. Kendala lain ialah kemampuan orang tua menyediakan fasilitas seperti smarphone dan laptop, serta penggunaan internet yang memakan biaya (Purwanto, dkk., 2020). Orang tua juga belum terbiasa menggunakan platform pembelajaran seperti zoom, google meet, dan berbagai platform lain yang digunakan dalam pembelajaran daring.

Kendala lain juga ditemui dalam hal ketersediaan waktu yang dimiliki oleh orang tua untuk membersamai siswa saat belajar. Tidak semua orang tua memiliki waktu yang cukup (Wardani \& Ayriza, 2021) untuk membersamai siswa selama belajar di rumah karena harus bekerja atau kesibukan lainnya. Masalah pekerjaan ditambah dengan menemani anak belajar yang terkadang susah diatur justru membuat orang tua semakin stress.

Kondisi saat ini mendesak untuk melakukan inovasi dan adaptasi terkait pemanfaatan teknologi yang tersedia untuk mendukung proses pembelajaran (Ahmed, dkk., 2020). Berbagai permasalahan yang ada dalam pembelajaran di masa covid-19 ini membutuhkan respon yang cepat, tepat dan akurat khususnya dari pimpinan sekolah. Dalam proses tata kelola sekolah akan berjalan dengan baik karena kepemimpinan kepala sekolah yang cepat tanggap (Nadeak \& Juwita, 2020) menghadapi pandemi. Kepala sekolah memikul tanggung jawab terhadap kenyamanan dan ketertiban lingkungan sekolah serta warga sekolah termasuk dalam hal keamanan dan kenyamanan di masa tanggap darurat Covid19 (Firmansyah \& Kardina, 2020).

Di sinilah peran kepemimpinan kepala sekolah sangat diperlukan dalam merancang proses belajar mengajar mulai dari persiapan, pelaksanaan, monitoring, dan evaluasi sehingga tenaga pendidik dan peserta didik sebagai pengguna layanan dapat mengikuti proses belajar mengajar dengan baik (Djumiko, Fauzan, \& Jailani, 2020). Tanpa kepemimpinan yang baik maka proses dan tata kelola sekolah akan terhambat.

Kepala sekolah dituntut untuk menerapkan manajemen krisis, yaitu proses mempersiapkan dan mengelola situasi darurat atau tidak terduga yang mana ancaman tersebut sudah terjadi dan harus dihadapi. Dalam manajemen krisis ini 
pimpinan harus mampu mempengaruhi siswa, guru, staf, orang tua wali, serta pemangku kepentingan (Murfi, Fathurrochman, \& Jannah, 2020). Langkah ini diharapkan mampu menjaga kondusifitas sekolah dan praktik pembelajaran di masa pandemi.

SD Lazuardi Tursina Banyuwangi menjadi tempat yang menarik untuk diteliti karena mampu membangun inovasi di tengah pandemi. Proses transisi dari pembelajaran tatap muka di kelas menjadi pembelajaran daring dapat dilaksanakan dengan baik. Pertanyaan kemudian ialah bagaimana proses kepemimpinan di sekolah ini sehingga tetap menjaga kualitas meskipun suasana dan lingkungan sedang mengalami krisis?

\section{B. Metode Penelitian}

Penelitian ini merupakan penelitian deskriptif kualitatif. Subjek penelitian pada penelitian ini adalah direktur, kepala sekolah, dan guru di SD Lazuardi Tursina Banyuwangi, sedangkan sumber data diambil dari berbagai data yang relevan dengan penelitian ini dan ditekankan pada kepemimpinan serta proses pembelajaran yang dilaksanakan di masa covid-19.

Pengumpulan data dilakukan dengan teknik wawancara mendalam, observasi pembelajaran daring, dan dokumentasi sekolah. Data yang terkumpul kemudian dilakukan analisis data dengan analisis interaktif yang terdiri dari tiga langkah kegiatan yaitu reduksi data, penyajian data, dan penarikan kesimpulan. Keabsahan data dilakukan dengan memperpanjang waktu pengamatan secara berkelanjutan dan terus menerus serta diuji dengan triangulasi (Miles dkk., 2014).

\section{Hasil dan Pembahasan}

SD Lazuardi Tursina merupakan SD yang berada di Jalan Borobudur No 4 Dadapan Banyuwangi Jawa Timur. Selama masa covid-19 SD Lazuardi Tursina tetap melakukan proses pembelajaran secara daring. Hal ini bukan hal yang mudah bagi seluruh warga sekolah, semua membutuhkan penyesuaian, koordinasi dan kerjasama yang baik antara Direktur, kepala sekolah, guru, wali siswa serta siswa sendiri. 
Awal pelaksanaan pembelajaran secara daring di SD Lazuardi Tursina tentunya banyak kendala yang dihadapi baik oleh orang tua siswa, siswa maupun guru. Di sini, pengelolaan sekolah yang baik dari pimpinan sangat diperlukan agar proses pembelajaran dan persekolahan dapat berjalan dengan baik. Beberapa hal yang dilakukan oleh pimpinan SD Lazuardi Tursina pada masa covid (Nurwiarsih, 2020) antara lain:

Pertama, melakukan penyederhanaan kurikulum. Penyederhanaan struktur kurikulum dilakukan oleh kepala sekolah dengan mengambil tindakan "amputasi" dengan memilih materi yang paling diperlukan, memetakan Kompetensi Dasar (KD) lebih cermat, dan memotong beberapa KD yang berulang atau dirasa tidak perlu. Penyederhanaan ini dilakukan bukan asalasalan tetapi melalui kajian mendalam. Penyederhanaan kurikulum ini juga dilakukan melalui koordinasi antara Direktur, Kepala Sekolah, dan Guru (Pangastuti, 2021).

Penyederhanaan kurikulum ini dilakukan sesuai dengan keputusan menteri pendidikan dan kebudayaan republik Indonesia nomor 719/P/2020 tentang pedoman pelaksanaan kurikulum pada satuan pendidikan dalam kondisi khusus. Penyederhanaan ini bertujuan untuk memberikan fleksibilitas bagi satuan pendidikan untuk menentukan kurikulum sesuai dengan kebutuhan pembelajaran siswa. Materi inti yang dipilih dalam penyederhanaan kurikulum berorientasi pada pembentukan karakter dan pengembangan diri. Sementara materi penunjang atau pengembangan tidak dimasukkan dalam kurikulum.

Kedua, Direktur, kepala sekolah serta guru selalu berkoordinasi dan berdiskusi secara intens terkait berbagai penyesuaian teknik, strategi, model dan metode pembelajaran yang dilakukan. Hal ini dilakukan agar layanan pembelajaran masa pandemi berlangsung optimal. Kepala sekolah selalu mendorong guru untuk selalu melakukan inovasi dalam proses pembelajaran melalui daring. Komunikasi dan koordinasi antar lini yang dilakukan secara inten mampu menemukan solusi dari permasalahan yang dihadapi warga sekolah terutama berkaitan dengan pembelajaran.

Pembelajaran daring (Anugrahana, 2020) atau proses e-learning sebagai media distance learning ini menciptakan paradigma baru, yakni peran guru lebih 
bersifat sebagai fasilitator dan siswa sebagai peserta aktif. Oleh karenanya, guru dituntut untuk dapat menciptakan teknik mengajar menarik. Beberapa kegiatan yang dilakukan di SD Lazuardi Tursina dalam proses pembelajaran daring antara lain yaitu dengan memperbanyak proyek-proyek yang dapat membantu siswa pempelajari banyak hal serta memberikan kesempatan kepada siswa untuk belajar secara langsung.

Kegiatan literasi digital juga ditambahkan seperti kunjungan virtual ke tempat yang dapat membuat siswa bertambah pengetahuan dan sesuai kompetensi dasar yang perlu dicapai. Beberapa Virtual tour yang dilakukan antara lain yaitu melakukan fieldtrip ke Taman Mini Indonesia Indah (TMII), Museum Penerangan, Kebun raya, diskusi dengan teman dari sekolah lain, dan lain kegiatan lainnya. Berikut contoh kegiatan virtual tour yang telah dilakukan di SD Lazuardi Tursina Banyuwangi.
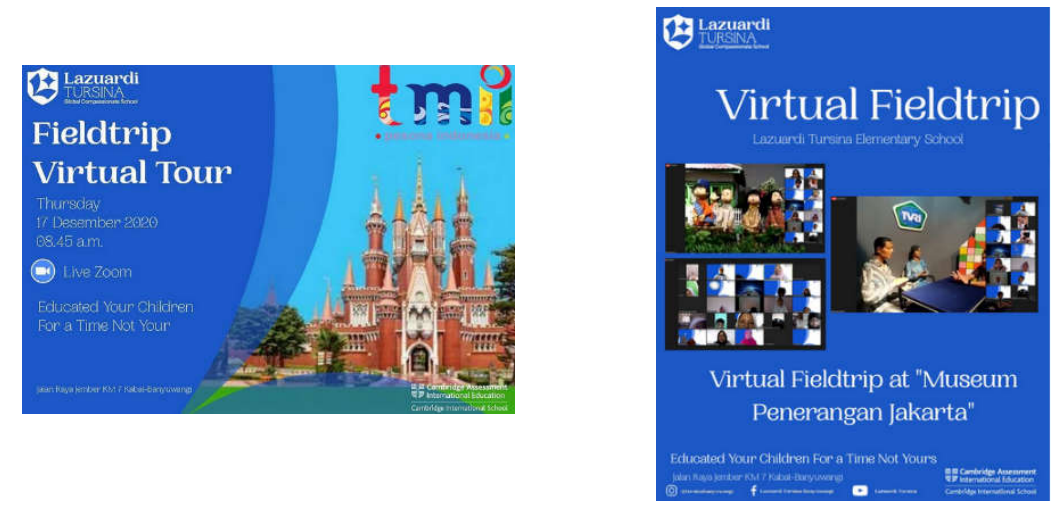

Gambar 1. Kegiatan Virtual Tour

Beberapa kegiatan proyek yang telah dilakukan antara lain yaitu membuat proyek pop up paper, membuat kerajinan, dan lain sebagainya. Pembelajaran berbasis proyek (Khanifah, Mustaji, \& Nasution, 2019) dapat meningkatkan hasil belajar jika diimplementasikan dalam pembelajaran khususnya di sekolah dasar. Lebih lanjut (Wibowo, 2014) menyampaikan bahwa pembelajaran dengan mengimplementasikan model pembelajaran project based learning dapat meningkatkan kemampuan 4C (communication, collaboration, creativity, critical thinking) sebagai bekal tantangan di abad 21.

Tidak hanya itu, (Rahmi, 2017) pembelajaran berbasis proyek juga sekaligus dapat meningkatkan kreativitas siswa. Para siswa dituntut menghasilkan proyek atau karya baik individual maupun berkelompok sehingga 
memicu kreativitas, kerjasama, dan tanggung jawab dari siswa. Meskipun dilakukan secara daring tetapi pembelajaran berbasis proyek mampu meningkatkan minta belajar anak dan tetap menyenangkan.

Beberapa kegiatan proyek yang dilakukan di SD Lazuardi Tursina Banyuwangi dapat dilihat pada gambar berikut.
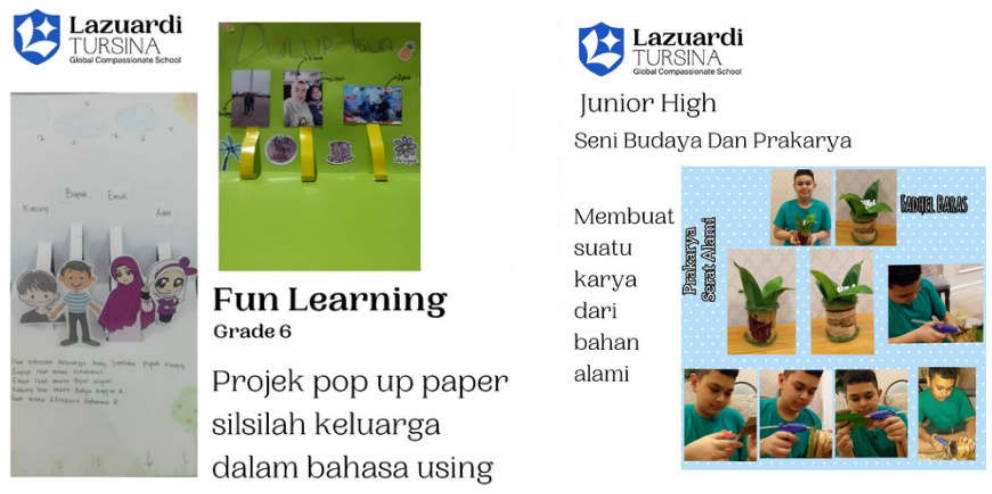

Gambar 2. Berbagai proyek yang telah dilakukan

Ketiga, pengelolaan anggaran yang lebih fleksibel. Pada masa covid-19 ini, pimpinan melakukan perubahan postur anggaran dari keperluan fisik menjadi keperluan yang mendukung proses pembelajaran daring seperti keperluan media pembelajaran, pelatihan pembelajaran dengan metode terbaru, kerjasama dengan berbagai layanan menjadi salah satu hal yang harus dipertimbangakan. Hal ini harus dilakukan karena adanya perubahan kebutuhan dari proses pembelajaran luar jaringan (luring) menjadi dalam jaringan (daring). Pada masa pandemi ini pembelajaran dilakukan secara daring melalui media pembelajaran yang variatif seperti zoom, google meet, google classroom, dan media whatsapp untuk kasus-kasus khusus (Kusumawati, 2020).

Pengelolaan anggaran ini merupakan potensi yang sangat menentukan keberhasilan layanan pendidikan dan merupakan bagian yang tak terpisahkan dalam manajemen pendidikan (Arwildayanto, Lamatenggo, \& Sumar, 2017). Para pimpinan di SD Lazuardi memberikan prioritas pendanaan pada pengembangan kompetensi guru dan pengadaan sarana prasarana penunjang pembelajaran daring. Dengan demikian tidak ada alasan pandemi kemudian tidak menjalankan pembelajaran dengan baik.

Keempat, melakukan evaluasi secara berkelanjutan terhadap kebijakankebijakan yang telah diambil disesuaikan dengan situasi dan kondisi yang ada. 
Beberapa evaluasi yang dilakukan misalnya saja dengan mengurangi jam belajar dari 35 menit tiap jam mata pelajaran menjadi 30 menit. Penempatan guru juga dipetakan ulang menjadi untuk satu guru hanya 5 siswa dengan ketentuan khusus (Nurwiarsih, 2020). Evaluasi ini merupakan hal yang sangat penting dalam setiap kegiatan agar mengetahui kegiatan tersebut tecapai tidaknya sasaran (Rusmini, 2018). Evaluasi juga dapat dijadikan sebagai proses penggambaran dan penyempurnaan informasi yang berguna untuk menetapkan alternatif (Asrul, Ananda, \& Rosnita, 2015).

Evaluasi yang dilaksanakan yakni pengumpulan data dan informasi terkait kebijakan dan dampaknya bagi pembelajaran. Kebijakan yang baik akan dipertahankan sementara yang kurang berdampak akan dievaluasi dan diganti dengan kebijakan baru yang lebih relevan. Proses ini berlangsung secara terusmenerus dan berkesinambungan.

Kelima, Direktur, kepala sekolah dan guru selalu melakukan komunikasi yang baik dengan orang tua siswa dan siswa agar proses pembelajaran daring tetap berjalan dengan baik. Hal tersebut penting karena pada masa covid-19 ini dinamika wali siswa atas kejenuhan pembelajaran daring, tingkat partisipasi siswa dalam proses pembelajaran. Partisipasi orang tua menjadi penentu keberhasilan kegiatan belajar dari rumah.

Orang tua berperan sebagai pembimbing, pendidik, penjaga, pengembang sekaligus sebagai pengawas dalam kegiatan pembelajaran selama kegiatan belajar dari rumah (Kurniati dkk, 2021). Pelibatan orang tua dalam pembelajaran daring terutama untuk jenjang pendidikan dasar mutlak diperlukan. Kehadiran orang tua diharapkan mampu membantu menanamkan nilai-nilai yang tidak dapat diajarkan melalui pembelajaran daring.

Dukungan sistem untuk pelibatan orang tua perlu digalakkan dan menjadi kebijakan penting di SD Lazuardi Tursina. Sesi quality time virtual dengan pembicara Nasional atau lainya diagendakan dengan tujuan semata-mata untuk terus memberi pemahaman kepada orang tua bahwa tanggung jawab mendidik adalah tanggung jawab bersama. Penting bagi sekolah memastikan hal ini terjadi karena sekolah, keluarga, dan masyarakat sebagai tri pusat pendidikan harus saling mendukung. Berikut beberapa contoh apresiasi yang diberikan kepada 
orang tua wali terhadap perjuangannya dalam mendampingi para siswa dalam kegiatan belajar dari rumah.

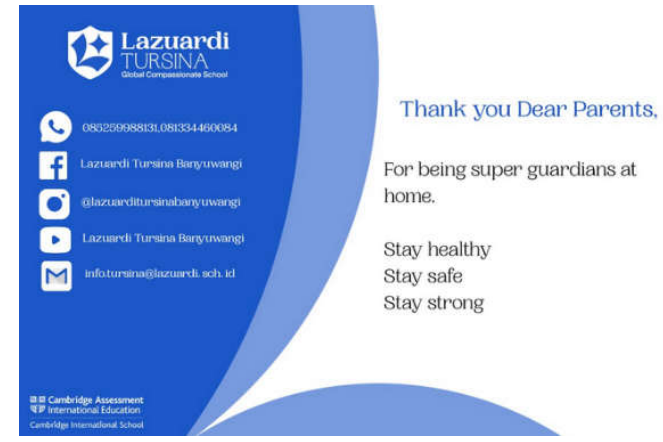

Gambar 3. Contoh Apresiasi sekolah Terhadap orang tua wali dalam mendampingi kegiatan belajar dari rumah

Keenam, kerjasama yang baik dengan berbagai aspek. Modal sosial yang dimiliki sekolah harus dimanfaatkan semuanya, kolega, wali siswa, jaringan semuanya dimanfaatkan, mereka semua dapat menjadi instrumen yang menguatkan sekolah selama masa pandemi ini. Kerjasama (Rosita \& Leonard, 2015) dapat mempercepat tujuan pembelajaran karena komunitas belajar selalu lebih baik dari pada individu. Kerjasama dengan stakeholder dan lembaga atau organisasi lain terus dilakukan sehingga dapat menunjang pembelajaran di SD Lazuardi tetap berkualitas. Kerjasama ini sekaligus untuk terus menjalin komunikasi dan membangun hubungan yang saling menguntungkan.

\section{Kesimpulan}

Berdasarkan pemaparan di atas, maka dapat disimpulkan bahwa kepemimpinan yang dilakukan dalam pengelolaan sekolah dasar khususnya di SD Lazuardi Tursina pada masa covid-19 ini antara lain yaitu dengan melakukan: 1) penyederhanaan kurikulum; 2) melakukan koordinasi dan diskusi secara intens antara direktur, kepala sekolah dengan guru-guru terkait penyesuaian teknik, strategi, model dan metode pembelajaran yang dilakukan dalam pembelajaran daring; 3) pengelolaan anggaran yang lebih fleksibel; 4) evaluasi secara berkelanjutan terhadap kebijakan yang telah dilaksanakan; 5) komunikasi yang baik antara sekolah dengan orang tua; dan 6) kerjasama yang baik dengan berbagai aspek. Kepemimpinan tersebut mampu membuat SD Lazuardi tetap menjalankan pembelajaran yang berkualitas. 


\section{E. Ucapan Terima Kasih}

Ucapan terimakasih diberikan kepada pimpinan SD Lazuardi Tursina Banyuwangi yang telah berbagi pengetahuan terkait kepemimpinan yang dilakukan di masa covid-19 ini.

\section{Daftar Pustaka}

Ahmed, S., Shehata, M., \& Hassanien, M. (2020). Emerging Faculty Needs for Enhancing Student Engagement on a Virtual Platform. MedEdPublish, 1(5). https://doi.org/https://doi.org/10.15694/mep.2020.000075.1

Aji, R. H. S. (2020). Dampak covid-19 pada pendidikan di Indonesia: sekolah, keterampilan dan proses pembelajaran. SALAM: Jurnal Sosial dan Budaya Syar-i. 7(5). 395-402. Doi: 10.15408/sjsbs.v7i5.15314.

Anugrahana, A. (2020). Hambatan, Solusi dan Harapan: Pembelajaran Daring Selama Masa Pandemi Covid-19 Oleh Guru Sekolah Dasar. Scholaria: Jurnal Pendidikan dan Kebudayaan, 10(3)

Arwildayanto, Lamatenggo, N., Sumar, W.T. (2017). Manajemen Keuangan dan Pembiayaan Pendidikan. Widya Padjadjaran.

Asrul, Ananda, R., Rosnita. (2015). Evaluasi Pembelajaran. Citapustaka Media.

Dewi, W. A. F. (2020). Dampak Covid-19 terhadap Implementasi Pembelajaran Daring di Sekolah Dasar. Edukatif: Jurnal Ilmu Pendidikan, 2(1)

Djumiko, D., Fauzan, S., \& Jailani, M. (2020). Panduan Kepala Sekolah untuk Mengelola Sekolah pada Masa Pandemic Covid-19. Pedagogik: Jurnal Pendidikan, 15(2)

Firmansyah, Y., \& Kardina, F. (2020). Pengaruh New Normal di tengah Pandemi Covid-19 terhadap Pengelolahan Sekolah dan Peserta Didik. Buana Ilmu, 4(2)

Herliandry, L. D., Nurhasanah, Suban, M. E., \& Kuswanto, H. (2020). Pembelajaran Pada Masa Pandemi Covid-19. Jurnal Teknologi Pendidikan, 22(1)

Huang, C., Wang, Y, et.al. (2020). Clinical features of patients infected with 2019 novel coronavirus in Wuhan, China. The Lancet 395 (10223)(2020): 497-506. https://doi.org/10.1016/S0140-6736(20)30183-5.

Khanifah, L. N. (2019). Pengaruh pengguaan model projecr based learning dan keterampilan kolaborasi terhadap hasil belajar siswa kelas IV sekolah dasar pada tema cita-citaku. Jurnal Review Pendidikan Dasar: Jurnal Kajian Pendidikan dan Hasil Penelitian. 5(1).

Kurniati, E., Alfaeni, D.K N., Andriani, F. (2021). Analisis peran orang tua dalam mendampingi anak di masa pandemic covid-19. Jurnal Obsesi: Jurnal Pendidikan Anak Usia Dini. 5(1). 241-256. 
Kusuma, J. W., \& Hamidah. (2020). Platform Whatsapp Group dan Webinar Zoom dalam Pembelajaran Jarak Jauh pada Masa Pandemik Covid 19. Jurnal Ilmiah Pendidikan Matematika, 5(1)

Kusumawati, H. (2020). Wawancara

Miles, M. B., Huberman, A. M., \& Saldana, J. (2014). Cross-case data analysis. In Qualitative data analysis: An expanded sourcebook.

Murfi, A., Fathurrochman, I., Jannana, N. S. (2020). Kepemimpinan Sekolah dalam Situasi Krisis Covid-19 di Indonesia. Manageria: Jurnal Manajemen Pendidikan Islam, 5(1). 119-136.

Nadeak, B., \& Juwita, C. P. (2020). Kepemimpinan Kepala Sekolah dalam Menjaga Tata Kelola Sekolah Selama Masa Pandemi Covid-19. Jurnal Konseling dan Pendidikan, 8 (3)

Nurwiarsih. (2020). Wawancara

Pangastuti, P. (2021). Wawancara

Purwanto, A., Pramono, R., Asbari, M., Santoso, P. B., Wijayanti, L. M., Hyun, C. C., \& Putri, R. S. (2020). Studi Eksploratif Dampak Pandemi COVID-19 terhadap Proses Pembelajaran Online di Sekolah Dasar. Journal of Education, Psychology, and Counseling, 2(1)

Rahmi, H. (2017). Penerapan model project based learning untuk meningkatkan kreativitas siswa dalam tema berbagai pekerjaan pada min masjid raya banda aceh. Skripsi. Aceh: Universitas Islam Negeri Ar-Raniry.

Rosita, I., Leonard. (2015). Meningkatkan kerja sama siswa melalui pembelajaran kooperatif tipe think pair share. Jurnal Formatif. 3(1). 1-10.

Rusmini. (2018). Aplikasi dan evaluasi kebijakan (analisis kebijakan walikota jambi tentang penghapusan pungutan sekolah dari masyarakat). Proceeding the 1 Annual Conference on Islamic Education Management (ACIEM). Yogyakarta: FITK UIN Sunan Kalijaga. 853-865.

Wardani, A. \& Ayriza, Y. (2021). Analisis Kendala Orang Tua dalam Mendampingi Anak Belajar di Rumah Pada Masa Pandemi Covid-19. Jurnal Obsesi: Jurnal Pendidikan Anak Usia Dini, 5 (1)

Wardhani, I. S. (2020). Peranan orang tua dalam pembelajaran daring di sekolah dasar. Skripsi. Bandung: Universitas Pasundan.

Wibowo, W.S. (2014). Implementasi model project based learning (Pjbl) dalam pembelajaran sains untuk membangun 4cs skills peserta didik sebagai bekal menghadapi tantangan abad 21. Prosiding Semniar nasional IPA V Tahun 2014. Yogyakarta: Universitas Negeri Yogyakara. 
Kepemimpinan Sekolah Dasar di Masa Covid-19 